\title{
Conus Medullaris Position in an Adult Population: Analysis of Magnetic Resonance Imaging
}

\author{
Posición del Cono Medular en una Población Adulta: \\ Análisis con Imágenes de Resonancia Magnética
}

\author{
Ozlen Karabulut*; Hatice Akay**; Zulfu Karabulut"***; Hüseyin Özevren****; \\ Gunay Saka $^{* * * * *}$; Savas Hatipoglu* \& Engin Deveci*******
}

KARAbUlUT, O.; AKAY, H.; KARABUlUT, Z.; ÖZEVREN, H.; SAKA, G.; HATIPOGLU, S. \& DEVECI, E. Conus Medullaris position in an adult population: Analysis of magnetic resonance imaging. Int. J. Morphol., 34(4):1352-1356, 2016.

SUMMARY: The objective of this study was to evaluate the variation in position of the conus medullaris $(\mathrm{CM})$ in male and female patients without spinal deformity, to correlate the termination level in magnetic resonance (MR) images of the lumbar spine. 921 patients consisted of 607 men and 314 women were evaluated by MRI. The strength of T1 weighted MRI device was 1.5 Tesla. The patients were in supine position when measured. The termination level of the conus medullaris was recorded in relation to the upper, middle or lower third of the adjacent vertebra and the adjacent intervertebral disc. The patients in our study group were examined for low back pain. The members with spinal deformity were excluded. The distribution of conus medullaris localization was measured to range from T12 to L2-L3. There was a statistically significant difference in the mean conus medullaris position related to gender also a significant difference between increasing age and conus position in female patients. These findings suggest that the distribution of CM location in a large adult population was shown to range from the upper third of T12 to the lower third of L2-L3 disc space both in women and men.

KEY WORDS: Conus medullaris; MRI.

\section{INTRODUCTION}

The termination level of Conus Medullaris (CM) can be found up to the disc between the second and third lumbal vertebra. It is important to know the termination level of the $\mathrm{CM}$ as an objective guide in selection of a safe intervertebral space when a physician applies lumbar puncture or myelography since the insertion of the intrathecal needles or catheters may lead to injuries in the case of spinal cord with lower termination. Spinal anatomy teaching were commonly derived from cadaveric studies so the shape and the position of the CM in a large adult population previously has been shown with the use of these studies (Reimann \& Anson, 1944; Saifuddin et al., 1998; Mirjalili et al., 2012). Previous studies have shown the termination of the CM to be between the middle third of T12 and L3 with a peak incidence at the lower third of L1 (Broadbent et al., 2000). During development of the embryo the vertebral column elongates more rapidly than the spinal cord in vertical direction.
The earlier growing of the primitive mesoderm than the neuroectoderm results in a relative shortening of the spinal cord and more rapid growth of vertebral column and duramater (Vettivel, 1991).

In the human embryo, the spinal cord fills whole length of the vertebral canal so the cord and the canal lie side by side. At the $30 \mathrm{~mm}$ crown-rump length (CRL) the proportional growth in length begins to disappear. The tip of the cord gradually seems at higher levels than the tip of the CM. At $24^{\text {th }}$ week of intrauterine life, the termination level of the CM corresponds to the level of first sacral vertebra. The spinal cord extends to the level of the second or third lumbar vertebra at birth (Malas et al., 2001). It has been reported that the length of CM reaches the mean adult population measurement results by two years of age at a mean position of L1 to L2 (Wilson \& Prince, 1989). Medulla spinalis narrows caudally to the Conus Medullaris. The

* Department of Anatomy, Faculty of Medicine, University of Dicle, Diyarbakir, Turkey.

** Department of Radiology, Veni Vidi Hospital, Diyarbakir, Turkey.

**** Department of Physical Medicine and Rehabilitation, VeniVidi Hospital, Diyarbakir, Turkey.

***** Department of Neurosurgery, Faculty of Medicine, University of Dicle, Diyarbakir, Turkey.

****** Department of Public Health, Faculty of Medicine, University of Dicle Diyarbakir, Turkey.

******** Department of Histology and Embryology, Faculty of Medicine, University of Dicle, Diyarbakir, Turkey. 
absolute apex of the CM describes its position. The distribution of CM position was at the upper third of L1 but can range between the middle third of T12 and the upper third of L3 (Moussallem et al., 2014). The mean conus position range was between the middle third of $\mathrm{T} 12$ to the upper third of L3 in cadaveric studies (Moore \& Persaud, 1998). In the adult CM terminates at the level of the disc between the first and the second lumbar vertebral bodies and also lies approximately in the transpyloric plane. However it may end below this level in $40 \%$ of subjects. Rarely it ends as high as the caudal third of twelfth thoracic vertebrae (Standring, 2009).

The tip of the CM is used to determine its position. The identification of the position of the CM is possible on sagittal, T1 weighted MRI assessments. We aimed to analyze the range of termination level of $\mathrm{CM}$ and correlate its position with age and sex in a living adult population by MRI demonstration.

\section{MATERIAL AND METHOD}

The study was performed on 921 lumbar spines by Magnetic Resonance Imaging (MRI) with the patients in the supine position. The study population consisted of consecutive patients in a range of 16-84 years of age who had been referred for MRI to analyze variable causes of low back pain. Patients with spinal deformity and with previous spinal operation history were excluded. T-1 weighted sagittal and axial spin-echo MRI studies of the lumber spine were reviewed. Studies were performed at 1.5 Tesla strength. Slice thickness for sagittal sequences was 4 $\mathrm{mm}$. Axial sequences were obtained from pedicle to pedicle and angled to the disc space. The position of the conus was defined in relation to the vertebrae.

Table I. Distribution of the conus termination levels according to the spinal level as number and percentage.

\begin{tabular}{llrrr}
\hline Conus position no & Spinal Level & Count & Percentage & Cumulative \% \\
\hline 1 & T12 upper & 1 & 0.1 & 1 \\
2 & T12 middle & 8 & 1 & 2 \\
3 & T12 lower & 6 & 0.7 & 2.6 \\
4 & T12-L1 & 81 & 7.8 & 10.4 \\
5 & L1 upper & 132 & 14.3 & 24.7 \\
6 & L1 middle & 165 & 17.9 & 42.6 \\
7 & L1 lower & 142 & 15.4 & 58.0 \\
8 & L1-L2 & 272 & 29.5 & 87.5 \\
9 & L2 upper & 54 & 5.9 & 93.4 \\
10 & L2 middle & 47 & 5.1 & 98.5 \\
11 & L2 lower & 13 & 1.4 & 99.9 \\
12 & L2-L3 & 1 & 0.1 & 100.0 \\
\hline
\end{tabular}

The most distal point of the cord could be visualized on the sagittal sequence was defined as the conus position or the termination level of the cord. The previous studies have shown the termination level of the $\mathrm{CM}$ to be between T12 and L3 and the absolute termination level of the conus traditionally was used to describe its position. According to the method of Saifuddin et al., each unit of a vertebra and intervertebral space was divided into four segments. The vertebral body was divided into three equal portions. The three portions of the vertebra were denominated upper, middle and lower thirds. The fourth segment was the adjacent intervertebral disc space as a separate region. For the aim of statistical analysis each segment was assigned a segmental number. The upper third of T12 vertebral level was segment 1 and L2-L3 intervertebral disc was segment 12 in our study group. Statistical tests including the student's $t$ test and analysis of variance were performed.

\section{RESULTS}

The study group consisted of 607 women and 314 men with a mean age of 40.57 years. The range of age was between 16 and 84 years. The mean age was $43.72 \pm 15.01$ for women and $40.57 \pm 15.38$ for men. The distribution of conus localization in a large adult population was measured to range from T12 to L2-L3 disc space. Pearson Correlation test was performed statistically for comparing age and conus localization. There was a positive correlation between age and conus position in women and the difference was significant $(\mathrm{p}=0.036)$ but there was not a significant correlation in men when the same variables compared $(\mathrm{p}=0.282)$. The termination level was measured in lower position with increasing age in both sexs (Table I).

We analyzed the termination level according to sex. When the localization of termination level analyzed for women the following values were found: $0.2 \%$ at the level of upper third of T12, $0.7 \%$ at the middle third of T12, $0.6 \%$ at the lower third of $\mathrm{T} 12,8.2 \%$ at the level of T12-L1, $11.1 \%$ at the upper third of $\mathrm{L} 1,19.6 \%$ at middle third of $\mathrm{L} 1$ level, $14.1 \%$ at the lower third of L1 level, 33.6 $\%$ L1-L2, $5.7 \%$ at the upper third of L2 level, $5.1 \%$ at the middle third of L2 level, $1.6 \%$ at the lower third of L2, 0.2 at L2-L3 level. The mean conus level was $6.95 \pm 1.76$ for women. The same values for men differed as the following: $0.5 \%$ at the middle third of T12, $0.4 \%$ at the lower third of T12, $13.7 \%$ at T12-L1 
level, $15.4 \%$ upper third of L1, $22.7 \%$ middle third of L1, $16.7 \%$ at the lower third of L1, 25.1\% at L1-L2, $2.7 \%$ at the upper third of L2, $2 \%$ at the middle third of L2 and 1.7 $\%$ at the lower third of L2. The mean level was $6.57 \pm 1.73$ for men. The most common termination level was L1-L2 both in women $(33.7 \%)$ and men $(22.8 \%)$. The least significant termination level was the lower third of L2 both in women $(1.3 \%)$ and men $(2 \%)$. Table 1 provides the conus positions according to twelve levels. The data providing the conus positions for women and men are represented graphically in Figure 1 for men and in Figure 2 for women. The mean conus level was $6.82 \pm 1.76$ and matched with the level between L1 and L2. The median value of termination level was the lower third of L1 in women and it was middle third of L1 for men. The relationship between termination level and sex was analyzed by Pearson Correlation analysis. The difference of termination level of CM was statistically significant between two sexs. (Pearson Chi-Square $\mathrm{c} 2=23.167, \mathrm{p}=0.002$ ).

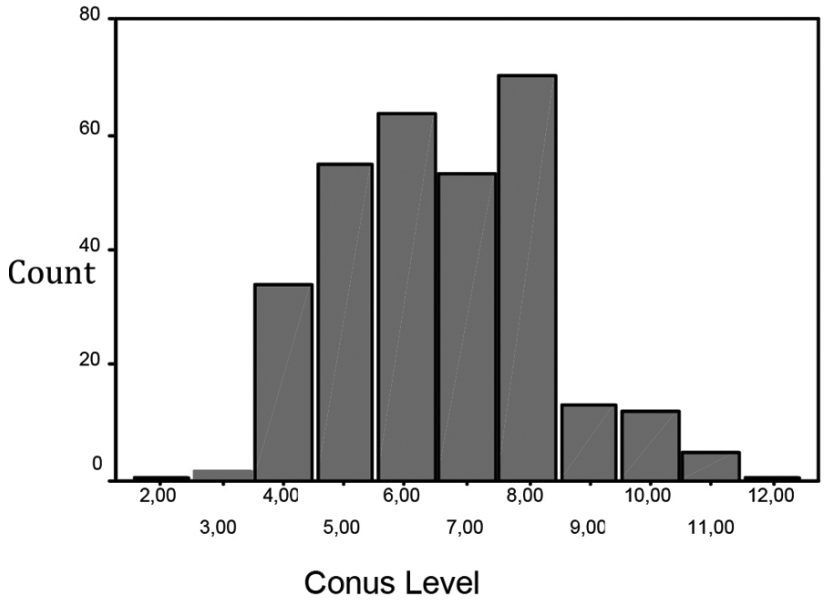

Fig. 1. Distribution of the conus termination level according to the spinal level for men.

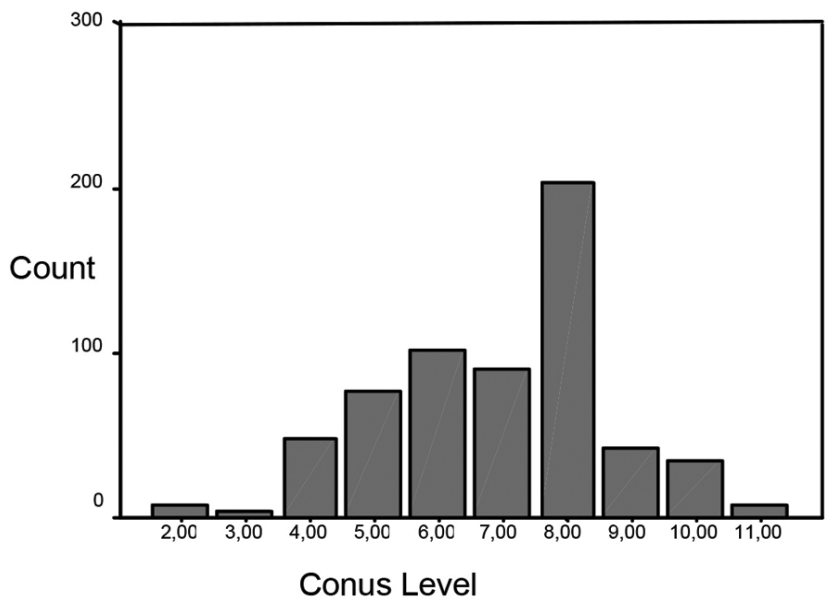

Fig. 2. Distribution of the conus termination level according to the spinal level for women.
The study population was divided into subgroups of age in decades. When conus positions cross tabulated with age decades by descriptive statistics, the mean level was reported L1 lower in all groups except 20-29 age decades in women. The conus position correlated L1 lower in three groups but upper termination levels in all other groups. The relationship between age and termination level was analyzed by Pearson Correlation test. There was a significant difference between age and conus position in female patients ( $\mathrm{p}=0.036$ ) but not any significant difference between conus position and increasing age in men $(\mathrm{p}=0.282)$.

\section{DISCUSSION}

There were many cadaveric studies performed previously for the aim of determining conus termination level. Thomson found the conus termination at L2 in $43 \%$ in women and $27 \%$ in men. In his study the range for the cord termination was between the lower third of T12 and the upper third of L3 (Thomson, 1894). McCotter found that the cord terminated between the upper third of L1 and the upper third of L2 in $77 \%$ of men in his study (McCotter, 1916). He also reported a lower termination for women but didn't find a significant difference between two sexs. The lowest level for the termination was the lower third of L3 in the same study (McCotter). Since the older patients with osteoporosis or age related vertebral deformity usually have a reduced height of the vertebral body the segmental position of the conus could be relatively lower (Diacinti et al., 1995; Pluijm et al., 2000). Reiman \& Anson examined 129 cadavers and also made a combination by using the previous reported studies of conus termination level and showed the mean termination level as lower third of L1. It was not reported whether those studies included the specimens with spinal deformities or congenital anomalies (Reimann \& Anson).

The utilization of MRI has provided the determination of the conus position in living individuals. The superiority of MRI was to be in correlation with life situations when compared with cadaveric studies and the ability of eliminating spinal deformities like transitional vertebrae when compared with plain radiographs. The prevalence of transitional vertebra has been reported as ranging between as $8-15 \%$.

The MRI reports of termination level, correlated these cadaveric studies in previous studies (Reimann \& Anson; Saifuddin et al.). Reimann reported the mean cord termination level L1-L2 position with a range between T12 lower and L3 middle thirds (Reimann \& Anson). Malas et 
al., showed the localization of the conus at L1 $62.5 \%$ and between L1 and L2 $21.8 \%$. In another study conducted by Demiryürek et al. (2002), the conus position was found at L1 44.4\%. Grewal \& Tarpey (2001) showed that the conus position varied from middle third of T12 to upper third of L3 and the mean position was L1 lower. Saifuddin et al., found the conus termination between T 12 middle and L3 upper range. The mean position was L1 lower with a standard deviation of one half of a spinal level in the same study (Saifuddin et al.). In our study the mean conus position was between $\mathrm{L} 1$ and $\mathrm{L} 2$ with a range between T12 and L2-L3 intervertebral disc.

Saifuddin et al., found men to have a longer cord. Malas et al., didn't find significant difference between sexs. There was a significant difference between sexs in the study conducted by Demiryürek et al. A significant difference was determined between sexs in our study.

In previous studies termination level of conus between T12 lower and L2 lower were in normal distribution. The mean termination level in our study indicates a normal distribution for the conus position. It is important to be conscious of the conus position in the course of performing lumbar puncture or myelography. Therefore, the better the anatomy of this region is known, the more confidently and effectively the interference will be performed. In majority of cases conus termination localization is higher than L2 therefore lumbar puncture should be performed below L2. Lumbar puncture at L2-3 or above is usually necessary in the case of spinal stenosis which is most detected at L3-L4, L4-L5. The results of Saifuddin showed a minimal risk to the conus from neddle cathetering at the level above L2-L3, because only $1.19 \%$ patients had a conus termination at or below L2-L32. Y Similarly we found only one conus terminated at L2-L3 disc. A significant proportion of cases showed higher termination than L2.

In addition to confidence of lumber puncture, the variation in conus position also sheds light on the differences among the neurologic injuries at the thoracolumbar junction. Since the volume of the canal which is occupied by neural tissue effects the grade of the neurologic injury, there was not a significant correlation between the degree of posttraumatic canal occlusion and neurologic situation when we excluded the level of the injury as related to the termination level of the CM.

Comparative knowledge on the termination of $\mathrm{CM}$ can help the physicians to achieve more successful results in insertions like lumbar puncture and myelography.

KARABULUT, O.; AKAY, H.; KARABULUT, Z.; ÖZEVREN, H.; SAKA, G.; HATIPOGLU, S. \& DEVECI, E. Posición del cono medular en una población adulta: Análisis con imágenes de resonancia magnética. Int. J. Morphol., 34(4):1352-1356, 2016.

RESUMEN: El objetivo de este estudio consistió en evaluar la variación en la posición del cono medular (CM) en pacientes masculinos y femeninos sin deformidad espinal, para correlacionar el nivel de terminación en imágenes de resonancia magnética (RM) de la columna lumbar. Fueron evaluados por RM un total de 921 pacientes, 607 hombres y 314 mujeres. La fuerza ponderada del dispositivo de RM en T1 fue 1,5 Tesla. Los pacientes se ubicaron en posición supina al momento de la medición. El nivel de terminación del cono medular se registró en relación con el tercio superior, medio o inferior de la vértebra adyacente y el disco intervertebral adyacente. Los pacientes de nuestro grupo de estudio fueron examinados por dolor lumbar. Se excluyeron los individuos con deformidad espinal. La distribución de la localización del cono medular se midió, con variaciones entre T12 a L2-L3. Hubo una diferencia estadísticamente significativa en la posición media del cono medular relacionada con el sexo y también una diferencia significativa entre el aumento de la edad y la posición del cono medular en las mujeres. Estos hallazgos sugieren que la distribución de la ubicación del CM en una población adulta se encontró en un rango que se extendió desde el tercio superior de T12 al tercio inferior del espacio discal L2L3, tanto en mujeres como en hombres.

PALABRAS CLAVE: Cono medular; RMN.

\section{REFERENCES}

Broadbent, C. R.; Maxwell, W. B.; Ferrie, R.; Wilson, D. J.; GawneCain, M. \& Russell, R. Ability of anaesthetists to identify a marked lumbar interspace. Anaesthesia, 55(11):1122-6, 2000.

Demiryürek, D.; Aydingöz, U.; Aksit, M. D.; Yener, N. \& Geyik, P. O. MR imaging determination of the normal level of Conus Medullaris. Clin. Imaging, 26(6):375-7, 2002.
Diacinti, D.; Acca, M.; D`Erasmo, E.; Tomei, E. \& Mazzuoli, G. F. Aging changes in vertebral morphometry. Calcif. Tissue Int., 57(6):426-9, 1995.

Grewal, B. S. \& Tarpey, J. Damage to the Conus Medullaris following spinal anaesthesia: 3. Anaesthesia, 56(8):812-4, 2001. 
Malas, M. A.; Salbacak, A.; Büyükmumcu, M.; Seker, M.; Köylüoglu, B. \& Karabulut, A. K. An investigation of the Conus Medullaris termination level during the period of fetal development to adulthood. Kaibogaku Zasshi, 76(5):453-9, 2001.

McCotter, R. E. Regarding the length and extent of the human medulla spinalis. Anat. Rec., 10(9):559-64, 1916.

Mirjalili, S. A.; McFadden, S. L.; Buckenham, T.; Wilson, B. \& Stringer, M. D. Anatomical planes: are we teaching accurate surface anatomy? Clin. Anat., 25(7):819-26, 2012.

Moore, K. L. \& Persaud, T. V. N. The Developing Human. Clinically Oriented Embryology. $6^{\text {th }}$ ed. Philadelphia, Saunders, 1998. pp.458-60.

Moussallem, C. D.; El Masri, H.; El-Yahchouchi, C.; Abou Fakher, F. \& Ibrahim, A. Relationship of the lumbar lordosis angle to the level of termination of the Conus Medullaris and thecal sac. Anat. Res. Int., 2014:351769, 2014.

Pluijm, S. M.; Tromp, A. M.; Smit, J. H.; Deeg, D. J. \& Lips, P. Consequences of vertebral deformities in older men and women. J. Bone Miner. Res., 15(8):1564-72, 2000.

Reimann, A. F. \& Anson, B. J. Vertebral level of termination of the spinal cord with report of a case of sacral cord. Anat. Rec., 88(1):127-38, 1944

Saifuddin, A.; Burnett, S. J. \& White, J. The variation of position of the Conus Medullaris in an adult population. A magnetic resonance imaging study. Spine (Phila Pa 1976), 23(13):14526, 1998.

Standring, S. Gray's Anatomy. The Anatomical Basis of Clinical Practice. $40^{\text {th }}$ ed. Edinburgh, Elsevier Churchill Livingstone, 2009.

Thomson, A. Fifth Annual Report of the Committee of Collective Investigation of the Anatomical Society of Great Britain and Ireland for the Year 1893-94. J. Anat. Physiol., 29(Pt. 1):3560, 1894.

Vettivel, S. Vertebral level of the termination of the spinal cord in human fetuses. J. Anat., 179:149-61, 1991.

Wilson, D. A. \& Prince, J. R. John Caffey award. MR imaging determination of the location of the normal Conus Medullaris throughout childhood. A. J. R. Am. J. Roentgenol., 152(5):102932, 1989.

\section{Correspondence to:}

Prof.(PhD).Engin Deveci,

Dicle University Faculty of Medicine,

Department of Histology and Embriyology

Diyarbakir

TURKEY

Email:engindeveci64@gmail.com

Received: 27-04-2016

Accepted: 10-08-2016 